\title{
Public Library System in Thiruvananthapuram, Kerala: An investigation
}

\author{
V.P. Ajitha Kumari and A.T. Francis ${ }^{2}$ \\ 'Research Scholar, Department of Library and Information Science, Karpagam University, Coimbatore, India; \\ kumariajitha@gmail.com \\ 2Research Guide, Librarian, Kerala Agricultural University, Thrissur, India; francisaloor@yahoo.com
}

\begin{abstract}
Public libraries provide a wide range of information products and services to the benefit of its user community. A public library is considered as gateway to knowledge, freedom, prosperity and the development of the society. The individuals in a society must have fundamental human values as per the UNESCO declaration. These are acquired by well informed citizens through playing an active part in social affairs and exercising their democratic rights. Constructive participation and the development of democracy depend upon satisfactory education as well as free and unlimited access to knowledge, thought, culture and information provided by public libraries. This study examines the role of public libraries in Kerala society. An attempt was made to evaluate the use of A-Grade public libraries in Thiruvananthapuram District by the users, purpose of using libraries, and present an overview of public libraries. This study suggests ways of reorienting the public libraries with IT enabled sources and services for the better development of the community as a whole.
\end{abstract}

Keywords: Information Resources, Kerala State Library Council, Library Finance and Management, Library Legislation, Public Libraries

\section{Introduction}

Public libraries are considered as the treasure house of knowledge, cradle of culture and heritage of a country. Essential functions of all public libraries are collection, organization, preservation and dissemination of knowledge to all individuals in a country. The history of public libraries in Kerala started in 1829 with the establishment of Trivandrum public library (the present State Central Library), which is the oldest public library in India. This library was initially used only by the European community in Trivandrum and invitees of the Durbar of the Maharaja. In 1898, a registered society called Trivandrum Public Library Society under the Travancore Joint Stock Companies' Regulations decided to hand over the library to the Government and Sreemoolam Thirunal declared that the library would be open to the public. Prior to independence during 194547 , rural libraries in the Travancore State organized to form "All Travancore Grandhasala Sanghom" with nearly 5000 affiliated libraries. The slogan of the Sanghom was "Read and Grow", which later changed to "acquire literacy and get strengthened". It was coined by Panikkar (1974), the architect of Library Movement in Kerala. He led the Sangham for 32 years until 1977, when the Sanghom was taken over by the State Government. It is now known as the Kerala State Library Council(KSLC) ${ }^{10}$.

Development of the public libraries in States is the responsibility of the respective State governments. Nineteen States and one Union Territory in India have enacted public libraries Act enabling smooth functioning of the public libraries. The KSLC is an autonomous body under the higher education department of the Government of Kerala formed as per the Kerala Public Libraries (Kerala Grandhasala Sangham) Act, 19 The organization of Public Libraries in Kerala has a three uer system, viz, State Library Council, District Library Council, and Taluk Library council and they are classified into six grades from $\mathrm{A}$ to $\mathrm{F}$.

*Author for correspondence 


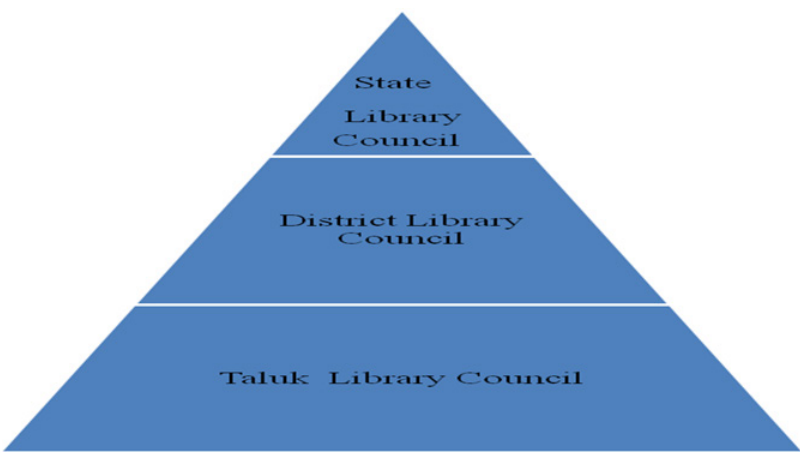

Figure 1. Three tier system envisaged in the Kerala Public Libraries Act, $1989^{9}$.

Figure 1 shows the three tier system envisaged in the Kerala Public Libraries Act, 1989.

The IFLA/UNESCO guidelines ${ }^{5,6}$ state that "Adequate levels of funding are crucial to the success of a public library in fulfilling its role". The cess and government grants are two major sources of the revenue for the public libraries in Kerala. In section 30 of Kerala Public Libraries Act $^{9}$, there is a provision for government grant to the State Library Council. According to this provision, "an amount of not more than one percent set apart for education in the State budget shall be provided to the State Library Council by the State Government". There are provisions "to collect library cess, the amount equal to $5 \%$ of building tax levied by the municipalities and corporations and land tax levied by the Panchayaths". The State Library Council collects this amount. Raja Rammohan Roy Library Foundation (RRRLF) also provides financial assistance to the State Library Council under matching and non-matching schemes. The other sources of income include revenue from user fees such as membership fee, subscriptions, donations etc.

\section{Review of Related Literature}

The various definitions of public library stress its vital role in the society. Mc Colvin ${ }^{12}$ states that "it is provided by the local authority, the town, or country council, entirely or mostly at its own expense; governed and administered by the authority or a committee, wholly or largely appointed by itself; available free of any charge to all who live in its area; and offering a wide selection of materials chosen to embrace as completely as possible the varied interests of the individual and the community, free from bias or religion, political or other motives." The IFLA/UNESCO Manifesto (1994) defines the public library as "the local gateway to knowledge, provides a basic condition for lifelong learning, independent decision making and cultural development of the individual and social groups, and a living force for education, culture and information, and as an essential agent for the fostering of peace and spiritual welfare through the minds of men and women". It exists from civilization of mankind and acts as an important custodian of human culture, knowledge and social customs ${ }^{7}$. It is necessary to maintain well trained and highly motivated staff to make effective use of the resources of the library and to meet the demands of the community.

Public library is a welfare centre which provides useful service to the community by fostering education, promoting culture, providing scope for healthy, recreation and disseminates information to all sections of the society $^{1}$.

Pe objectives of public libraries inherent in the standards for public libraries of U. K. Department of Culture (2004) are, they underpin education, providing essential support for school children, students, and lifelong learners; they enhance public access to the world's store house of knowledge and information; they promote social inclusion, by helping to bridge the gap between those who can afford access to information and those who can not; they have a role to play in the modernization and delivery of public services; and they provide information which underpins commercial and economic endeavour.

Various statements on the purpose of public libraries confirm that "the public library makes an essential contribution to democracy and citizenship. It is also vital to a nation's literacy and productivity" ${ }^{\text {. According }}$ to Mangla (201 1 vell accepted axiom that a library for democracy, universal self education and enlightenment is indeed a public library. In view of its vital role in public support and service to the people it is rightly described as a library of the people, for the people and by the peopl

\section{Objectives of the Study}

The specific objectives of the study are as follows:

- To evaluate the sources and services of A-Graded libraries in Thiruvananthapuram Taluk under the Kerala State Library Council;

- To evaluate the role of Kerala State Library Council in the overall development of public libraries;

- To identify the information needs of the users;

- To identify the obstacles, if any, in providing better services to the users; and

- To give suggestions for better services.

\section{Scope of the Study}

The study was limited to the Thiruvananthapuram revenue Taluk only. The data regarding the organisation, administration, resources, services and activities of the 
Table 1. Total number of public libraries affiliated to KSLC from 1965 to 2013 in Kerala

\begin{tabular}{lccc}
\hline Year & Number of libraries affiliated & Number of libraries added & Percentage growth in the number of libraries \\
\hline 1965 & 3297 & - & - \\
1975 & 4280 & 983 & 29.8 \\
1985 & 4928 & 648 & 15.1 \\
1995 & 5537 & 609 & 12.4 \\
2005 & 6608 & 1071 & 19.3 \\
2006 & 6640 & 32 & 0.5 \\
2007 & 6786 & 146 & 2.2 \\
2008 & 6913 & 127 & 1.9 \\
2009 & 7075 & 162 & 2.3 \\
2010 & 7191 & 116 & 1.6 \\
2011 & 7252 & 61 & 0.8 \\
2012 & 7410 & 158 & 2.2 \\
2013 & 7526 & 116 & 1.6 \\
\hline
\end{tabular}

libraries were collected from the librarians working in the A-Graded public libraries and users of the library in Thiruvananthapuram Taluk.

\section{Methodology}

The Taluk of Thiruvananthapuram possesses 57 A- Grade and 74 B-F Grade libraries, with a total of 131 public libraries. Out of this, all A Grade libraries were taken as sample. Extensive literature survey through magazines, journals, books, internet, and annual reports was done to reveal various facets of public libraries. For data collection, structured questionnaire supplemented by informal discussion, telephonic and face to face interviews were used. Data was collected from librarians and users of the library. Observational visits were also conducted to the libraries and information collected on the present set up of libraries.

\section{Analysis of Data}

The data were analyzed using simple statistical tools.

\subsection{Public Libraries Affiliated to KSLC}

Table 1 shows that the decadal growth in the number of libraries affiliated to KSLC was maximum (29.8\%) during 1965-75 followed by 1995-2005. The annual growth rate was maximum during 2008-2009 and minimum during 2005-2006 (19.3\%). Out of total 7526 public libraries affiliated to KSLC, 131 libraries were in Thiruvananthapuram Taluk, out of which 57 libraries were A-Graded.
Table 2. Number of Libraries affiliated to KSLC in Thiruvananthapuram Taluk during 2013-2014

\begin{tabular}{lc}
\hline A Grade & 57 \\
B Grade & 43 \\
C Grade & 10 \\
D Grade & 7 \\
E Grade & 9 \\
F Grade & 5 \\
\hline Total & 131 \\
\hline
\end{tabular}

\subsection{General Details of A-Grade Libraries}

Table 3. General Details of A- Grade Libraries

\begin{tabular}{lcc}
\hline Item & Number of libraries & Percentage \\
\hline Having Building & 54 & 95 \\
Having Computer & 57 & 100 \\
Professional Manpower & 5 & 9 \\
\hline
\end{tabular}

Table 3 shows that $95 \%$ of libraries had their own buildings and $100 \%$ of the libraries had Computers. Lack of professional manpower was a major hurdle in the management of the libraries. Only 9\% of the libraries had qualified librarians.

\subsection{Collection Development}

Table 4 shows that all the libraries had a minimum collection of 7000 books. Sixteen libraries (28\%) had collections between 10000 and 14000 and four libraries (7\%) had the highest number of books in the range of 26000-35000. The diagrammatic representation of the collection is given in Figure 2. 


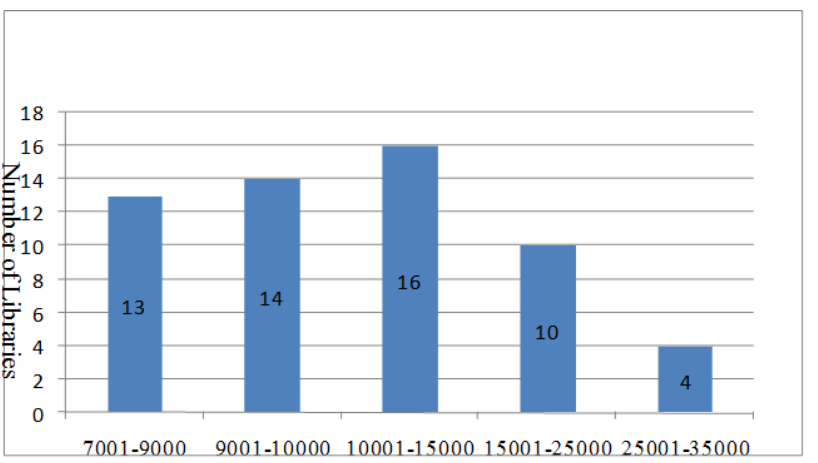

Figure 2. Distribution of A-Grade public libraries by stock of books.

Table 4. Books in A-Grade public libraries in Thiruvananthapuram Taluk during 2012-13

\begin{tabular}{lcc}
\hline Number of Books & Number of Libraries & Percentage \\
\hline $7001-9000$ & 13 & 23 \\
$9001-10000$ & 14 & 24 \\
$10001-14000$ & 16 & 28 \\
$15001-25000$ & 10 & 18 \\
$26000-35000$ & 4 & 7 \\
\hline TOTAL & 57 & 100 \\
\hline
\end{tabular}

Table 5. Magazines subscribed in the A-Grade public libraries

\begin{tabular}{lc}
\hline Name of magazine & \% of libraries subscribing \\
\hline Malayala Manorama & 73 \\
Mangalam & 40 \\
Manorjyam & 22 \\
Kumkumam & 18 \\
Grihalaksmi & 42 \\
Vanitha & 45 \\
Keralasabdam & 50 \\
Manasatram & 25 \\
Mathrubhumi & 92 \\
India today & 38 \\
Kalakaumudi & 62 \\
Desabhimani & 42 \\
Career guidance & 53 \\
Agricultural Magazines & 50 \\
Children's Magazine & 55 \\
\hline
\end{tabular}

Table 5 shows that most libraries subscribed to the Malayalam magazines. The magazines, which were found most popular, were Mathrubhumi (92\%), Malayala Manorama (73\%), and Kalakaumudi (62\%), Children's magazines (55\%), Career guidance (53\%), Keralasabdam and Agricultural magazines (50\%). Vanitha (45\%), Grihalaksmi and Desabhimani (42\%), Mangalam (40\%), Manassasthram (25\%), Manorajyam (22\%), Kumkumam (18\%), India Today (38\%), also had good readership among the sample libraries. Career guidance magazines and agricultural magazines were recent additions in the libraries. The pie diagram showing the subscription of magazines is given in Figure 3.

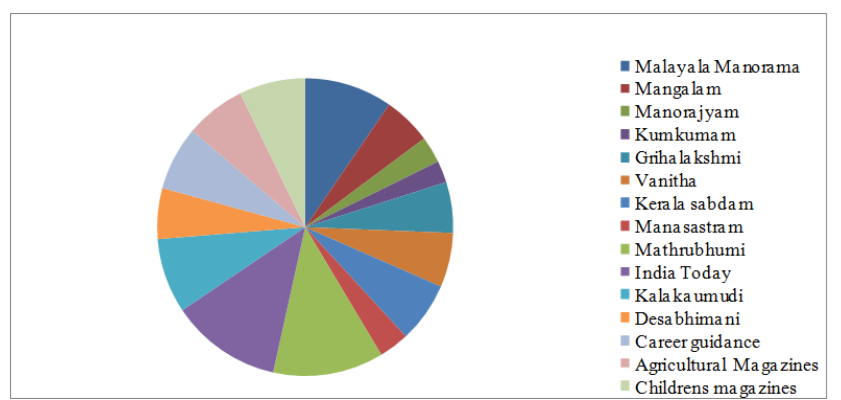

Figure 3. Subscription of Weeklies and Magazines.

\subsection{Library Users}

Data were collected from 456 (Table 6) users using the random sample method. It was found that 332 (73\%) were males and 124 (27\%) were females.

The age wise and category wise distribution of respondents are given in Table 7 which shows that $25 \%$ of the users were between $18-25$ years, $24 \%$ of the users were between the groups of $26-32$ years, $22 \%$ belonged to the age group of 33-40 and only $29 \%$ of the users were above 45 years. Among the users, $30 \%$ were in the unemployed category followed by students $(27 \%)$ and Government employees (22\%). Only $21 \%$ of the respondents were working in the private sector.

Table 6. Gender wise classification of Library Users

\begin{tabular}{lcc}
\hline Gender & Number of respondents & Percentage \\
\hline Male & 332 & 73 \\
Female & 124 & 27 \\
\hline Total & 456 & 100 \\
\hline
\end{tabular}

\subsection{Use Pattern}

The use pattern was analysed with respect to the frequency of visits and purpose of visit. The results are placed on Table 8.

Table 8 shows that $25 \%$ of respondents visited libraries once in a week, followed by $21 \%$ of respondents visited every day, $16 \%$ of respondents visited once in two weeks and $15 \%$ of respondents visited once in a month. It also shows that the main purpose of visiting the library was to 
Table 7. Distribution of the respondents by age and category

\begin{tabular}{lcclcc}
\hline & Age-wise distribution & & \multicolumn{3}{c}{ Category-wise distribution } \\
\hline Age Group & Number of respondents & Percentage & Category & Number of respondents & Percentage \\
\hline $18-25$ & 113 & 25 & Students & 125 & 27 \\
$26-32$ & 110 & 24 & Govt. employees & 100 & 22 \\
$33-40$ & 102 & 22 & Unemployed & 135 & 30 \\
Above 45 & 131 & 29 & Private sector & 96 & 21 \\
\hline Total & 456 & 100 & Total & 456 & 100 \\
\hline
\end{tabular}

Table 8. Frequency and purpose of visit of Users to the A-Graded Public Libraries

\begin{tabular}{|c|c|c|c|c|c|}
\hline \multicolumn{3}{|c|}{ Frequency of visit to library } & \multicolumn{3}{|l|}{ Purpose of visit to library } \\
\hline Frequency & No. of respondents & $\%$ & Purpose & Number of visitors & $\%$ \\
\hline Every day & 96 & 21 & Newspaper reading & 210 & 46 \\
\hline Once a week & 112 & 25 & Recreational purpose & 125 & 28 \\
\hline Once in two weeks & 75 & 16 & To prepare for competitive examinations competitive Exams & 50 & 11 \\
\hline Once a month & 67 & 15 & Information about employment news & 42 & 9 \\
\hline Occasionally & 106 & 23 & Others & 29 & 6 \\
\hline Total & 456 & 100 & Total & 456 & 100 \\
\hline
\end{tabular}

read newspapers (46\%), recreation (27\%) and prepare for competitive examinations (11\%). Most of the respondents opined the need for extending the working hours of the libraries.

\subsection{Extension Activities of the A-Graded Public Libraries}

Major extension activities undertaken by the libraries were Balavedi for Children, a special programme for children; Production of Handicrafts; Vanithavedi, a programme for women empowerment; Agriculture literacy programs, Information technology programme, etc. Some other extension activities organized were given here:

- Jail Libraries;

- Orphanage Libraries;

- Tribal Libraries;

- Heritage Libraries;

- Academic Study Centers;

- Rural Book Circulating Programs;

- Model Village Librarie;

- Taluk Reference Libraries;

- Hospital Libraries;

- Reading contest for the students; and

- Tuition classes for the socially backward students.

\section{Summary of Findings}

- The study shows that majority of the libraries were situated in the Corporation area and their collections mainly consisted of poetry, short stories and novels.
Printed books, mainly of Malayalam fiction, were the materials available in these libraries;

- Majority of the users visited the library for the purpose of reading newspapers and magazines;

- $95 \%$ of libraries possessed their own lands and buildings;

- The major information service provided by the public libraries was lending of books. Some libraries provided general information services including career information and user orientation;

- Majority of the libraries did not have any classified arrangement of books using any standard classification scheme and books were catalogued using local cataloguing methods and ledger form of cataloguing was followed;

- Non-professionals were engaged in majority of the libraries for managing the library with no essential computer knowledge; and

- The number of libraries that made effective use of computers was very less and most of them used computers mainly for data entry work.

\section{Suggestions}

- Library timings should be extended to evening hours.

- Collections must be properly classified and organised for effective rendering of service.

- All libraries should collect and provide necessary information in relevant areas such as agriculture, health and education, etc. 
- Develop local databases, bibliographical as well as full-text.

- Organize mobile library system to cover all geographical areas.

- Establish Public Library Network System connecting all libraries that come under the Kerala State Library Council with other institutions engaged in rural development activities.

- Establish a new set up of dynamic information centres with the help of the latest information technology to effectively cater to the information needs of the people.

- Qualified professionals with advanced ICT skills, management skills and other competencies should be engaged in these libraries for providing better services.

\section{Conclusion}

Public libraries have always been the door for learning for a large majority of the population that they serve. They are knowledge centers and contribute to lifelong learning. Public library can be described well as people's university. Proper functioning of the public library system will support other libraries, especially academic libraries. It is hoped that this study will provide valuable insights into the effective functioning of the public libraries and public library system in Kerala. Proper development and maintenance of the public library system along modern lines is a basic need of the society.

\section{References}

1. Abraham, L.T. (2010). Role of public libraries in non- formal education in Kerala Kelpro bulletin, 14: 60-67.

2. Anil, T. and Ramadevi T. (2001). Rural libraries: A comparative study in four states of India. Public Library Quarterly, 19: 43-55.

3. Dhawan, S.A.; Sardana, J.L.; Bhatt, R.K. and Jain M.K. (2010). Public Libraries in the Knowledge society: An Indian Experience. Delhi: Shipra publications.

4. Feather, John and Sturges, Paul op. cit.' 9, 381

5. IFLA/UNESCO. (2001). section of public libraries Public library service: IFLA/UNESCO guide lines for development. Munchen: K. G. Saur, Sec.2.4

6. IFLA/UNESCO. op.cit.,4,Para 1

7. Kaliya, P. and Bhaskaran, S. (2010). Information seeking behaviour of rural folk in Tamil nadu: A case study of peramkudi branch library Kelpro Bulletin, 4: 49-59.

8. Kerala District Library cound(D) nnual reports 2012-2013 to 2013-2014, Thiruvananthapuram.

9. Kerala Public Libraries Act, 1989

10. Kerala State Library Council Annual reports 2010-11 to 2013-2014.

11. Majeed, K.C.A. (2002). Social Development and Libraries: Service portfolio for a village Library. KELPRO Bulletin, 10: 34-42.

12. Mc Colvin, L.R. (1956). The chance to Read. London: Phoenix House; 12.

13. Palanivelu, C. and Raghavan, K.S. Education through public libraries - a practical approach, In Proceedings of the National Seminar on Public Library movement; concepts and Strategies, 19-21 April 1991, p. 302-31 